\title{
Browse Quality Response to Forest Fertilization and Soils in Florida
}

\author{
JOHN M. WOOD AND GEORGE W. TANNER
}

\begin{abstract}
Spring leaves of red maple (Acer rubrum) and inkberry (Ilex glabra) from slash pine (Pinus elliottii) plantations fertilized with diammonium phosphate 4 to 9 years prior to collection were higher in phosphorus $(P)$ than leaves from an unfertilized plantation. The nitrogen (N) content of inkberry leaves also was higher in spring. During the summer, in vitro organic matter digestibility (IVOMD) was higher in both species and $P$ was higher in inkberry on fertilized plantations. However, any residual effect of fertilization on nutrient concentrations was overshadowed by a decrease in $P$ and $\mathrm{N}$ and an increase in calcium (Ca) in the summer. The effect of soil series on nutrient values was negligible, with the exception of $\mathrm{Ca}$, which was higher on a somewhat poorly drained Dunbar soil series than on a poorly drained Bladen soil series. Nutritive value of both browse plants was limited by low IVOMD and $P$ concentrations, which never attained maintenance levels required by white-tailed deer (Odocoileus virginianus).
\end{abstract}

Use of fertilizer amendments in Southeastern forest stands is an increasingly common management practice. Additions of nitrogen (N) and phosphorus (P), particularly on poorly drained flatwoods soils, significantly increases growth and wood yield when applied in slash pine (Pinus elliottii) plantations early in the rotation (Pritchett and Smith 1975). In general, the nutritive value of many plant species increases, at least temporarily, following fertilization (Albrecht 1944, Mitchell 1955, Foote and Jacobs 1966, Basile 1970, Abell and Gilbert 1974, Goetz 1975). However, the degree of influence often varies with physiography, climate, soils (Beeson 1955, Lazar and Beeson 1956, Hundley 1959, Thacker and Beeson 1958, Kilmer et al. 1960, Thorsland 1966), and the overstory and understory species in question.

Follett et al. (1981:148) suggest that at least 1.6 million ha of forest in the Southeast would respond to fertilization. Opportunities for enhancement of wildlife resources in conjunction with timber management may be increasing with the acreage of fertilizcd pinc plantations. The purposc of this study was to determine the influence of fertilization and soil series in slash pine plantations on the nutritive value of common browse plants used by whitetailed deer (Odocoileus virginianus).

\section{Materials and Methods}

The study area included six 10 to 25 -ha, bedded (disced and mounded), slash pine plantations distributed within the northwestern portion of the Apalachicola National Forest, Liberty County, Florida (Wood 1982:8). The region is characterized by cool winters and hot, humid summers with average daily temperatures between $10^{\circ}$ and $27^{\circ} \mathrm{C}$, and average rainfall of $149 \mathrm{~cm} / \mathrm{yr}$ (National Oceanic and Atmospheric Administration 1980). All trees were planted on the beds in 1971 at an initial stocking density

\footnotetext{
Authors were graduate research assistant and assistant professor, Department of Wildlife and Range Sciences, School of Forest Resources and Conservation, University of Florida, Gainesville 32611. Wood now is wild life biologist, Florida Game and Fresh Water Fish Commission, 3991 SE 27 th Court, Okeechobee 33474.

The authors thank M. Cohen, M.C. McLeod, C.E. Reed, W.S. Terry, and W.R. Waite for field and laboratory aid, J.L. Kepner and R.C. Littell for statistical advisement, and P.G. Bohatl, N.B. Comerford, H.L. Ghol, I. D. Harris, C.E. Lewis, W.L. Pritchett. and A.V. Zale for manuscript review. Data were analyzed with the facilities of the Northeast Regional Data Center of the State University System of Florida, University of Florida, Gainesville.

This paper was submitted as University of Florida Agr. Exp. Sta. Journal Series No. 5317. Funding was provided by U.S. Forest Service Cooperative Agreement No. 19-306.

Manuscript accepted April 15, 1985
}

of 1,500 trees/ ha. One plantation had never been fertilized, 1 was fertilized in 1972 with $225 \mathrm{~kg}$ / ha diammonium phosphate $(18-21 \%$ $\mathrm{N}, 20-23 \% \mathrm{P}, \mathrm{pH} 8.0$ ), and 4 were fertilized in 1975-1976 with diammonium phosphate at the same application rate. All plantations occurred on a poorly drained Bladen soil (clayey, mixed, thermic family of Typic Ochraquults) and/or a somewhat poorly drained Dunbar soil (clayey, kaolinitic, thermic family of Aeric Paleaquults). Both are Ultisols and characteristic of flatwoods in northern Florida with a $\mathrm{pH}$ less than 4.5. Under such acidic conditions, soluble iron $(\mathrm{Fe})$ and aluminum $(\mathrm{Al})$ particles may react with phosphate ions to form insoluble $P$ compounds, which are not readily available for uptake by some plants (Ballard and Pritchett 1974).

The experimental design was a nested analysis of variance, testing the effect of fertilization on in vitro organic matter digestibility (IVOMD), calcium (Ca), $\mathrm{P}$, and $\mathrm{N}$ in the foliage of red maple (Acer rubrum) and inkberry (llex glabra) plants growing naturally in the understory of the pine plantations. The variable nested within fertilization treatments was soil series. Analysis of unbalanced data was executed with the general linear model (GLM) procedure in the Statistical Analysis System (SAS Institute 1982). Significant $(P<0.05)$ differences between fertilization treatment means were determined with the Turkey-Kramer studentized range test for unequal cell sizes (SAS Institute 1982:172). The results of the Student's $t$-test between regression coefficients (SAS Institute 1982:180) were used to determine significant $(P<0.05)$ differences between soil series means within fertilization treatments.

Leaves from the same randomly selected red maple and inkberry plants were collected within each soil series-fertilization experimental unit in each plantation in August 1980 (summer) and in April 1981 (spring). Ten samples were replicated each season within most experimental units. A minimum of 7 individual plants was sampled when not enough plants were growing on the site. We collected leaves that were produced in 2 different growing seasons to reduce the effect that harvesting might have on nutritive value. Differences $(P<0.05)$ between seasons and species were analyzed separately from the effects of fertilization and soil series and were based on the Student's $t$-test.

Inkberry and red maple were chosen over the other plants normally eaten by deer because they were the only white-tailed deer forage (Harlow 1961, Harlow and Jones 1965, Blair and Brunett 1980) common enough in these plantations for sampling purposes. Foliage within reach of foraging deer (less than $1.5 \mathrm{~m}$ above the ground) was stripped by hand from each plant and bagged separately. We attempted to collect only current year's growth, which we determined was the leaves on green, terminal portions of inkberry twigs (an evergreen species) and any of the leaves of red maple (a deciduous species). Foliar samples were placed in a cooler and covered with dry ice until reaching the laboratory. They were transferred directly to a drying oven for at least 48 hours at $60^{\circ} \mathrm{C}$, then ground through a $1-\mathrm{mm}$ sieve in a Wiley mill and stored in air-tight, Whirl-Pak bags. The petioles of red maple leaves were removed before grinding and not used in the experiments to reduce this potential source of variability in nutritive value (Hacker and Minson 1981).

Foliar IVOMD was determined with rumen fluid obtained from a fistulated steer fed grass hay and supplemented daily with a ration of soybean meal, salt, fluorinated phosphate, and vitamin A. A highly significant correlation between cow in vitro and deer in 
Table 1. Seasonal and specific differences in browse quality in ten-year-old slash pine plantations, Apalachicola National Forest, Florida. The in vitro organic matter digestibility (IVOMD), calcium (Ca), phosphorus (P), and nitrogen (N) means represent percentages on a dry matter basis.

\begin{tabular}{|c|c|c|c|c|c|c|c|c|c|}
\hline \multirow[b]{2}{*}{ Species } & & \multicolumn{4}{|c|}{ Summer 1980} & \multicolumn{4}{|c|}{ Spring 1981} \\
\hline & & IVOMD & $\mathrm{Ca}$ & $\mathbf{P}$ & $\mathbf{N}$ & IVOMD & $\mathrm{Ca}$ & $\mathbf{P}$ & $\mathbf{N}$ \\
\hline$\overline{\text { Red Maple }}$ & $\begin{array}{c}\bar{X} \\
\mathrm{SE} \\
n\end{array}$ & $\begin{array}{c}39.3 \\
0.4 \\
100\end{array}$ & $\begin{array}{c}0.431 \\
0.016 \\
100\end{array}$ & $\begin{array}{c}0.070 \\
0.002 \\
100\end{array}$ & $\begin{array}{l}1.31 \\
0.02 \\
100\end{array}$ & $\begin{array}{c}39.1 \\
0.4 \\
99\end{array}$ & $\begin{array}{c}0.243 \\
0.008 \\
99\end{array}$ & $\begin{array}{c}0.110 \\
0.003 \\
99\end{array}$ & $\begin{array}{c}1.72 \\
0.02 \\
99\end{array}$ \\
\hline lnkberry & $\begin{array}{c}\bar{X} \\
\mathrm{SE} \\
n\end{array}$ & $\begin{array}{c}29.4 \\
0.3 \\
97\end{array}$ & $\begin{array}{c}0.452 \\
0.009 \\
97\end{array}$ & $\begin{array}{c}0.051 \\
0.001 \\
97\end{array}$ & $\begin{array}{c}1.06 \\
0.01 \\
97\end{array}$ & $\begin{array}{c}36.6 \\
0.4 \\
97\end{array}$ & $\begin{array}{c}0.204 \\
0.006 \\
97\end{array}$ & $\begin{array}{c}0.137 \\
0.002 \\
97\end{array}$ & $\begin{array}{c}1.74 \\
0.02 \\
97\end{array}$ \\
\hline
\end{tabular}

vivo digestibility values was reported by Palmer et al. (1976). The IVOMD procedure followed was the two-stage Tilley and Terry (1963) method, revised by Moore and Mott (1974). Nitrogen concent rations were determined in 0.25 -g samples by a micro-Kjeldahl procedure (Bremner 1965) revised by Nelson and Sommers (1973). Additionally, $0.50-\mathrm{g}$ samples were ashed for 4 hours at $500^{\circ} \mathrm{C}$ and dissolved in dilute $\mathrm{HCl}$, which allowed $\mathrm{Ca}$ to be determined by atomic absorption (Mitchell and Rhue 1979) and P by the Murphy and Riley (1962) ascorbic acid method.

\section{Results and Discussion}

\section{Season and Species}

For both red maple and inkberry, $N$ and $P$ concentrations were lower $(P<0.01)$ and $\mathrm{Ca}$ concentrations were higher $(P<0.01)$ in August than in April (Table 1). The structural function of $\mathrm{Ca}$ in cell membranes may explain the higher $\mathrm{Ca}$ concentrations of both species during the summer. This function immobilizes $\mathrm{Ca}$ in intercellular space and in phloem, unlike $P$ and $N$, which readily leach from senescent leaves (Fitter and Hay 1981:76).

Digestibility of red maple was not significantly different between summer and spring, but IVOMD of inkberry was lower $(P<0.01)$ in summer. The spring-to-summer decline in IVOMD of inkberry's foliage presumable was due to the cutinization and lignification suggested by morphological changes (i.e., increased thickness, rigidity, and a waxy buildup on the epidermis). Red maple foliage did not exhibit such morphological changes.

Phosphorus concentrations of inkberry foliage were higher $(P<0.01)$ than red maple in the spring, but lower in the summer. Inkberry flowers and fruits in summer, while red maple does so carly in the spring. Many of the inkberry plants selected for this study were observed to be in flower or fruit, but no evidence of flowering or seed production was observed on any of the red maple plants. Translocation of $P$ into actively growing tissue (Reader 1978) may explain the lower concentrations of inkberry in summer.

Browse is considered the staple forage type over most whitetailed deer range due to its year-round availability. However, neither of the browse plants that were studied provided adequate nutritional levels of IVOMD (Ammann et al. 1973:200) or P (Magruder et al. 1957, Ullrey et al. 1975). Browse comprised $43 \%$ of the volume of 515 rumen samples collected in late fall and winter in Florida (Harlow and Jones 1965:97). Of the 159 species of genera identified, only 78 were browse (Harlow and Jones 1965:8396). To meet nutritional requirements, white-tailed deer select a variable diet that includes forbs and grasses (Halls 1978, Thill 1984), fruits (Short and Epps 1976), and fungi (Miller and Halls 1969, Thill 1984).

\section{Soil Series}

Digestibility of inkberry foliage was higher $(P<0.05)$ on the Bladen series than on the Dunbar series in the spring (Table 2). Only $1.0 \mathrm{~cm}$ of rainfall was recorded in the vicinity of the study site during April 1981 (Tanner and Terry 1982). Inkberry plants growing on the better-drained Dunbar soil may have experienced some degree of water stress, causing an abatement of the rapid spring growth of succulent leaf tissue.

Foliar concentrations of $\mathrm{Ca}$ and $\mathbf{P}$ tended to be higher on the Dunbar series, though not all differences were significant. The increased solubility of $\mathrm{Fe}$ and $\mathrm{Al}$ ions in low $\mathrm{pH}$ soils may cause inhibition of $\mathrm{Ca}$ uptake and retention of soil $\mathrm{P}$ as oxides of $\mathrm{Fe}$ and Al (Fitter and Hay 1981:205). Ballard and Fiskell (1974) found the highest $P$ retention of $\mathbf{4 2}$ soil types in a Bladen soil.

Soil series had no significant effect on $\mathbf{N}$ concentrations of either species in either season.

\section{Fertilization}

In the spring, $P$ concentrations of both species, and $N$ concentrations of inkberry, responded to fertilizer that had been applied up to 9 years previously (Table 3 ). No response of red maple to fertilization, particularly during the summcr, may be related to a dilution effect (Duncan and Hylton 1970), wherein the additional $\mathbf{N}$ and $\mathbf{P}$ afforded the fertilized plants were used for increased growth. Leaching also may have been a factor.

Only $\mathbf{P}$ concentrations of inkberry browse responded to the residual cffect of fertilization during the summer. Perhaps this occurred because the leaves of this evergreen species take several years to mature as opposed to the deciduous, red maple. Under-

Table 2. Comparison of browse quality on two soil series within slash pine plantations fertilized in 1976.

\begin{tabular}{|c|c|c|c|c|c|c|c|}
\hline Season & Species & Soil series & $n$ & IVOMD & $\mathrm{Ca}$ & $\mathbf{P}$ & $\mathbf{N}$ \\
\hline \multirow{5}{*}{ Summer 1980} & & & & & & & \\
\hline & Red Maple & Bladen & 36 & 40.2 & 0.365 & 0.066 & 1.31 \\
\hline & & Dunbar & 39 & 39.2 & $0.446^{*}$ & $0.076^{*}$ & 1.30 \\
\hline & Inkberry & Bladen & 30 & 30.4 & 0.401 & 0.054 & 1.03 \\
\hline & & Dunbar & 39 & 29.6 & $0.461^{*}$ & 0.052 & 1.05 \\
\hline \multirow[t]{4}{*}{ Spring 1981} & Red Maple & Bladen & 35 & 38.4 & 0.207 & 0.111 & 1.68 \\
\hline & & Dunbar & 39 & 39.5 & $0.253^{*}$ & 0.120 & 1.74 \\
\hline & Inkberry & Bladen & 30 & $37.4 *$ & 0.192 & 0.139 & 1.73 \\
\hline & & Dunbar & 39 & 34.9 & 0.203 & 0.144 & 1.77 \\
\hline
\end{tabular}

*Significantly higher $(P<0.05)$ than on other soil series based on the Student's $t$-test. 
Table 3. Browse quality response to the residual effect of fertilization.

\begin{tabular}{|c|c|c|c|c|c|c|c|}
\hline Season & Species & $\begin{array}{l}\text { Year plantatation } \\
\text { fertilized }\end{array}$ & $n$ & IVOMD & $\mathrm{Ca}$ & $\mathbf{P}$ & $\mathbf{N}$ \\
\hline \multirow[t]{2}{*}{ Summer 1980} & Red Maple & $\begin{array}{l}\text { None } \\
1972 \\
1976\end{array}$ & $\begin{array}{r}19 \\
8 \\
73\end{array}$ & $\begin{array}{l}36.3 \mathrm{~b}^{1} \\
42.6 \mathrm{a} \\
39.7 \mathrm{a}\end{array}$ & $\begin{array}{l}0.536 \mathrm{e} \\
0.413 \mathrm{e} \\
0.407 \mathrm{e}\end{array}$ & $\begin{array}{l}0.070 \mathrm{e} \\
0.054 \mathrm{e} \\
0.071 \mathrm{e}\end{array}$ & $\begin{array}{l}1.36 \mathrm{a} \\
1.16 \mathrm{~b} \\
1.31 \mathrm{a}\end{array}$ \\
\hline & Inkberry & $\begin{array}{l}\text { None } \\
1972 \\
1976\end{array}$ & $\begin{array}{l}20 \\
10 \\
67\end{array}$ & $\begin{array}{l}27.8 \mathrm{~b} \\
27.6 \mathrm{~b} \\
30.0 \mathrm{a}\end{array}$ & $\begin{array}{l}0.511 \mathrm{e} \\
0.454 \mathrm{e} \\
0.435 \mathrm{e}\end{array}$ & $\begin{array}{l}0.042 \mathrm{~b} \\
0.054 \mathrm{a} \\
0.053 \mathrm{a}\end{array}$ & $\begin{array}{l}1.08 \mathrm{a} \\
1.08 \mathrm{a} \\
1.04 \mathrm{a}\end{array}$ \\
\hline \multirow[t]{2}{*}{ Spring 1981} & Red Maple & $\begin{array}{l}\text { None } \\
1972 \\
1976\end{array}$ & $\begin{array}{r}19 \\
8 \\
72\end{array}$ & $\begin{array}{l}38.4 \mathrm{a} \\
41.3 \mathrm{a} \\
39.0 \mathrm{a}\end{array}$ & $\begin{array}{l}0.279 \mathrm{e} \\
0.284 \mathrm{e} \\
0.232 \mathrm{e}\end{array}$ & $\begin{array}{l}0.088 \mathrm{~b} \\
0.103 \mathrm{ab} \\
0.116 \mathrm{a}\end{array}$ & $\begin{array}{l}1.79 \mathrm{a} \\
1.66 \mathrm{a} \\
1.71 \mathrm{a}\end{array}$ \\
\hline & Inkberry & $\begin{array}{l}\text { None } \\
1972 \\
1976\end{array}$ & $\begin{array}{l}20 \\
10 \\
67\end{array}$ & $\begin{array}{l}39.3 \mathrm{e} \\
34.9 \mathrm{e} \\
36.0 \mathrm{e}\end{array}$ & $\begin{array}{l}0.223 \mathrm{a} \\
0.213 \mathrm{a} \\
0.198 \mathrm{a}\end{array}$ & $\begin{array}{l}0.114 \mathrm{~b} \\
0.146 \mathrm{a} \\
0.141 \mathrm{a}\end{array}$ & $\begin{array}{l}1.62 \mathrm{~b} \\
1.86 \mathrm{a} \\
1.76 \mathrm{a}\end{array}$ \\
\hline
\end{tabular}

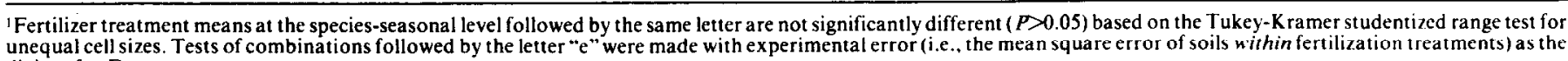
divisor for $F$

story species adapted to infertile sites grow slowly and, therefore, may tend to accumulate nutrients of limited availability over time (Chapin 1980). Evergreen shrubs, particularly, are adapted to Pdeficient soils (Loveless 1961, 1962, Beadle 1966, Monk 1966).

Calcium concentrations appeared to be lower in the fertilized treatments during the summer, but the differences were not significant because the experimental error (i.e., the mean squared error of soil series nested within fertilization) was high. Fertilization also increased IVOMD of both species during the summer. An increased period of growth and succulence that lasted into the summer also would account for the lower $\mathrm{Ca}$ and higher IVOMD percentages.

\section{Conclusions}

The daily $\mathrm{Ca}$ intake requirement for body maintenance of whitetailed deer is $0.25 \%$ and $1.2 \%$ for N (Magruder et al. 1957). For the most part, the $\mathrm{Ca}$ and $\mathrm{N}$ concentrations of inkberry and red maple foliage met or exceeded these requirements. In vitro digestibility of these 2 species, however, was insufficient to supply adequate digestible energy for body maintenance (Ammann et al. 1973:200). Likewise, $P$ concentrations of both browse species were well below proposed maintenance-level requirements of $0.28 \%$ to $0.30 \%$ (Magruder et al. 1957, Ullrey et al. 1975). Neither inkberry, a major constituent of fall and winter deer diets in northern Florida (Harlow 1979), nor red maple would provide adequate nutrition for growth and reproduction if fed upon alone, regardless of season or site characteristics. However, deer would need to consume about $22 \%$ less inkberry foliage in the summer, if they browsed in the fertilized plantations rather than in the unfertilized plantation, to obtain the same percentage of $P$ in the diet. Higher $P$ concentrations in fertilized plantations also may be true of inkberry that is browsed by deer in the fall and winter.

\section{Literature Cited}

Abell, D.H., and F.F. Gilbert. 1974. Nutrient content of fertilized deer browse in Maine. J. Wildl. Manage. 38:517-524.

Albrecht, W.A. 1944. Soil fertility and wildlife-cause and effect. Trans. North Amer. Wildl. Conf. 9:19-28.

Ammann, A.P., R.L. Cowan, C.L. Mothershead, and B.R. Baumgardt. 1973. Dry matter and energy intake in relation to digestibility in whitetailed deer. J. Wildl. Manage. 37:195-201.

Ballard, R., and J.G.A. Fiskell. 1974. Phosphorus retention in Coastal Plain forest soils: I. Significance to soil properties. Soil Sci. Soc. Amer. Proc. 38:250-255.
Ballard, R., and W.L. Pritchett. 1974. Phosphorus retention in Coastal Plain forest soils: II. Significance to forest fertilization. Soil Sci. Soc. Amer. Proc. 38:363-366.

Basile, J.V. 1970. Fertilizing to improve elk winter range in Montana. U.S. Forest Serv. Res. Note INT-113.

Beadle, N.C.W. 1966. Soil phosphate and its role in molding segments of the Australian flora and vegetation, with special reference to xeromorphy and sclerophylly. Ecology 47:992-1007.

Beeson, K.C. 1955. Nutrient element content of native forages in relation to location and land forms in the South Carolina coastal plain. Soil Sci. 80:211-220.

Blair, R.M., and L.E. Brunett. 1980. Seasonal browse selection by decr in a southern pine-hardwood habitat. J. Wildl. Manage. 44:79-88.

Bremner, J.M. 1965. Total nitrogen. P. 1149-1178. In: C.A. Black, ed. Methods of soil analysis. Amer. Soc. Agron., Madison, Wis. 2 Vols.

Chapin, F.S., III. 1980. The mineral nutrition of wild plants. Annu. Rev. Ecol. Sys. 11:233-260.

Duncan, D.A., and L.O. Hylton, Jr.1970. Effects of fertilization on quality of range forage. P. 57-62. In: Range and wildlife habitat evaluation-a research symposium. U.S. Forest Serv. Misc. Pub. No. 1147.

Fitter, A.H., and R.K.M. Hay. 1981. Environmental physiology of plants. Academic Press, New York.

Follett, R.H., L.S. Murphy, and R.L. Donahue. 1981. Fertilizers and soil ammendments. Prentice-Hall, Inc., Englewood Cliffs, N.J

Foote, L.E., and J.A. Jacobs. 1966. Response of partridge pea (Cassia fasciculata Michx.) and Korean lespedeza (Lespedeza stipulacea L.) to differences in soil types, phosphorus fertilization. and plant populations. Agron. J. 58:419-423.

Goetz, H. 1975. Effects of site and fertilization on protein content of native grasses. J. Range Manage. 28:380-385.

Hacker, J.B., and D.J. Minson. 1981. The digestibility of plant parts. Herbage Abstr. 51:459-482.

Halls, L.K. 1978. White-tailed deer. P. 42-65. In: J.L. Schmidt and D.L. Gilbert, eds. Big game of North America: ecology and management. Stackpole, Books, Harrisburg, Pa.

Harlow, R.F. 1961. Fall and winter foods of Florida white-tailed deer. Fla. Acad. Sci. J. 24:19-38.

Harlow, R.F. 1979. In defense of inkberry - dangers of ranking deer forage. Wildl. Soc. Bull. 7:21-24.

Harlow, R.F., and F.K. Jones, Jr. 1965. The white-tailed deer in Florida. Fla. Game and Fresh Water Fish Comm. Tech. Bull. No. 9.

Hundley, L.R. 1959. Available nutrients in selected deer-browse species growing on different soils. J. Wildl. Manage. 23:81-90.

Kilmer, V.J., O.L. Bennett, V.F. Stahly, and D.R. Timmons. 1960. Yield and mineral composition of eight forage species grown at four levels of soil moisture. Agron. J. 52:282-285. 
Lazar, V.A., and K.C. Beeson. 1956. Mineral nutrients in native vegetation on Atlantic Coastal Plain soil types. Agr. Food Chem. 4:439-444.

Loveless, A.R. 1961. A nutritional interpretation of sclerophylly based on differences in the chemical composition of sclerophyllous and mesophytic leaves. Annals Bot. N.S. 25:168-184.

Loveless, A.R. 1962. Further evidence to support a nutritional interpretation of sclerophylly. Annals Bot. N.S. 26:551-561.

Magruder, N.D., C.E. French, L.C. McEwen, and R.W. Swift. 1957. Nutritional requirements of white-tailed deer for growth and antler development: II. Experimental results of the third year. Penn. Agr. Exp. Sta. Bull. 628.

Miller, H.A., and L.K. Halls. 1969. Fleshy fungi commonly eaten by southern wildlife. U.S. Forest Serv. Res. Pap. SO-40.

Mitchell, C.C., Jr., and R.D. Rhue. 1979. Procedures used by the University of Florida Soil Testing and Analytical Research Laboratories. Soil Sci. Dep., Univ. Florida, Gainesville.

Mitchell, J.H. 1955. Some mineral nutrients found in South Carolina plants and the effect of fertilizer on the mineral content of the plants. South Carolina Agr. Exp. Sta., Clemson.

Monk, C.D. 1966. An ecological significance of evergreenness. Ecology 47:504-505.

Moore, J.E., and G.O. Mott. 1974. Recovery of residual organic matter from in vitro digestion of forages. J. Dairy Sci. 57:1258-1259.

Murphy, J., and J.P. Riley. 1962. A modified single solution determination of phosphate in natural waters. Anal. Chim. Acta. 27:31-36.

National Oceanic and Atmospheric Administration. 1980. Climatological data: Florida. Dep. Commerce, Nat. Climatic Cent., Asheville, N.C. Vol. 84.

Nelson, D.W., and L.E. Sommers. 1973. Determination of total nitrogen in plant material. Agron. J. 65:109-112.
Palmer, W.L., R.L. Cowan, and A.P. Ammann. 1976. Effect of inoculum source on in vitro digestion of deer foods. J. Wildl. Manage. 40:301-307.

Pritchett, W.L., and W.H. Smith. 1975. Forest fertilization in the U.S. Southeast. Proc. North Amer. Forest Soils Conf, 4:467-476.

Reader, R.J. 1978. Contribution of overwintering leaves to the growth of three broad-leaved, evergreen shrubs belonging to the Ericaceae family. Can. J. Bot. 56:1248-1261.

SAS Institute, Inc. 1982. SAS user's guide: statistics, 1982 edition. SAS Institute, Inc., Cary, N.C.

Short, H.L., and E.A. Epps, Jr. 1976. Nutrient quality and digestibility of seeds and fruits from southern forests. J. Wildl. Manage. 40:283-289.

Tanner, G.W., and W.S. Terry. 1982 . Vegetation inventory in the longleaf/slash pine forest type, Apalachicola National Forest, Florida. Final Report. Coop. Agreement No. 19-306. U.S. Forest Serv. South. Forest Exp. Sta., Alexandria, LA.

Thacker, E.J., and K.C. Beeson. 1958. Occurrence of mineral deficiencies and toxicities in animals in the United States and problems of their detection. Soil Sci. 85:87-94.

Thill, R.E. 1984. Deer and cattle diets on Louisiana pine-hardwood sites. J. Wildl. Manage. 48:788-798.

Thorsland, O.A. 1966. Nutritional analyses of selected deer foods in South Carolina. Proc. Southeast. Ass. Game and Fish Comm. 20:84-104.

Tilley, J.M.A., and R.A. Terry. 1963. A two-stage technique for the in vitro digestion of forage crops. J. Br. Grass. Soc. 18:104-111.

Ulirey, D.E., W.G. Youatt, H.E. Johnson, A.B. Cowan, L.D. Fay, R.L. Covert, W.T. Magee, and K.K. Keahey. 1975. Phosphorus requirements of weaned white-tailed deer fawns. J. Wildl. Manage. 39:590-595.

Wood, J.M. 1982. Nutritive value of deer browse related to soil and overstory characteristics in North Florida pine plantations. M.S. Thesis. Univ. Florida, Gainesville. 